\title{
Factors of Ethnic Conflict in the Ethiopian Federation
}

\author{
Factores de conflicto étnico en la Federación Etíope
}

Takele Bekele Bayu

National University of Public Service Budapest - Hungary

Budapest, Hungary

takeb21983@gmail.com

\section{ABSTRACT}

Since 1991 Ethiopia has made a change in thinking favoring federalism against the centralized hierarchical power to radically respond to the problem of diversity and better recognize and accommodate the country's ethnolinguistic and cultural diversity. Paradoxically, Ethiopia had experienced more ethnic-based conflict in its post-1991 existence than ever before. Among others, the Somali-Oromo conflict is the worst ethnic-based conflict in the country's history. Though the two communities, have a long tradition of co-existence and strong socio-cultural integrations due to their shared Muslim-Cushitic identity, economic interdependence, and shared cultural practices; antagonistic relationships, and intermittent conflicts due to resource competition, territorial expansion, bad governance, and other factors have prevailed in the last three decades. It is the objective of this paper, therefore, to investigate and analyze factors of ethnic conflict along the shared border of the Somali and Oromia regional administrations, specifically Bable and Bobas districts, within the context of Ethiopian federalism. Methodologically, the study employed a comparative research approach and made use of key informant interview and survey questionnaires' techniques in gathering the relevant data, and in effect, both qualitative and quantitative data interpretation and analysis methods were utilized in the analysis section. The findings of this study demonstrate that the Somali-Oromo conflict is complex \& dynamics and the result of the interplay of historical, institutional/structural/political, economic, sociocultural, and environmental factors. Furthermore, the result of the study reveals that major drivers of ethnic conflict in both areas are similar.

Keywords: Ethiopia; Oromo; Somali; Federalism; Ethnic conflict

\section{RESUMEN}

Desde 1991, Etiopía ha realizado un cambio de mentalidad favoreciendo el federalismo frente al poder jerárquico centralizado para responder radicalmente al problema de la diversidad y reconocer y acomodar mejor la diversidad etnolingüística y cultural del país. Paradójicamente, en su existencia posterior a 1991, Etiopía ha experimentado más conflictos de base étnica que nunca. Entre otros, el conflicto somalí-oromo es el peor conflicto de base étnica de la historia del país. Aunque las dos comunidades tienen una larga tradición de coexistencia y una fuerte integración sociocultural debido a su identidad musulmana-cusita, su interdependencia económica y sus prácticas culturales compartidas, en las últimas tres décadas han prevalecido las relaciones antagónicas y los conflictos intermitentes debidos a la competencia por los recursos, la expansión territorial, la mala gobernanza y otros factores. Por lo tanto, el objetivo de este trabajo es investigar y analizar los factores del conflicto étnico a lo largo de la frontera compartida de las administraciones regionales de Somalia y Oromia, concretamente los distritos de Bable y Bobas, en el contexto del federalismo etíope. Desde el punto de vista metodológico, el estudio empleó un enfoque de investigación comparativa y utilizó técnicas de entrevista con informantes clave y cuestionarios de encuesta para recopilar los datos pertinentes, y en efecto, en la sección de análisis se utilizaron métodos de interpretación y análisis de datos tanto cualitativos como cuantitativos. Las conclusiones de este estudio demuestran que el conflicto somalíoromo es una dinámica compleja y el resultado de la interacción de factores históricos, institucionales/estructurales/políticos, económicos, socioculturales y medioambientales. Además, el resultado del estudio revela que los principales impulsores del conflicto étnico en ambas zonas son similares.

Palabras clave: Etiopía; Oromo; Somalia; Federalismo; Conflicto étnico 


\section{INTRODUCTION}

Though Ethiopia has been a multiethnic state since its modern existence (the second half of the 19th century), for more than a century various successive governments had ignored and/or failed to provide political and legal protection to the inherent multicultural and multilingual realities of the nation (Tewfik, 2010; Mengistu, 2015). This has led to the "questions of nationalities/ethnic identities" in the country and the subsequent rise of ethnic-based armed struggles like the Eritrean People Liberation Front ( EPLF), the Tigrian People Liberation Front (TPLF), the Oromo Liberation Front (OLF), and the Ogaden National Liberation Front (ONLF) among others in demanding justice, self-administration, and redefine the identity of the state itself. Consequently, in 1991 a multi-national force led by Ethiopian People Revolutionary Front (EPRDF) took the political power in the country and constitutionally recognized and institutionally accommodated the country's ethnolinguistic and cultural communities while granting self-administration to the various distinct ethnic communities through federal arrangements. This is a paradigm shift and departure from the previous centralized monarchical and military rules in the sense that the new ethnic federalism puts the sovereignty of the state in the nations, nationalities, and people of Ethiopia (FDRE Constitution 1995). In effect, the Ethiopian state was restructured into nine ethnically divided regions based on the 7/1992 proclamation of the Transitional Government of Ethiopia (TGE) and the 1995 constitution restructured the state into nine ethnically divided regions. Among those regions, the study was conducted along the shared border of Oromo and the Somali regional administrations who share more than $1000 \mathrm{~km}$ long boundary.

Historically, Somalis and Oromo have a long tradition of co-existence and strong socio-cultural integrations due to their shared Muslim-Cushitic identity, economic interdependence, and shared cultural practices as well as antagonistic relationships and intermittent conflicts due to resource competition, territorial expansion, bad governance, and other factors (Abdulahi, 2005; Ali, 2005; Getachew, 2012). The conflict that dominates Ethiopia since 1991 in general and the Somali Oromo conflicts, in particular, are attributable to the broader political dynamics that are the changes in state and administrative boundaries given regime changes which resulted in rigid land and the boundary demarcation between territorialized ethnic groups (Abbink, 2006; Markakis, 1987). Despite the rationality of the federal administration in managing the complex ethno linguistic diversity of the country and reducing conflicts, the implementation of ethnic federalism in Ethiopia has led to the birth of new challenges i.e., ethnic competition and conflicts across the federation (Clapham, 2009; Abbink 2006; Temesgen 2015; ICG 2009; Hagmann and Abbink, 2011).

In the post-1991, the conflict in the area has exhibited a clear transformation from competition over the resource to local level territorial conflict and intra-federal boundary dispute with the involvement of multiple actors and forces and from a simple confrontation by using traditional weapons to war-like scenarios with modern and more sophisticated weaponry. This has increased the complexity and intractability of the conflict between the Oromo and the Somali communities. Hence, the nature, behaviors, and trends of conflict varied from time to time taking new forms and dynamics with huge repercussions. Ethnic conflict in the area today constitutes a dominant challenge to national, regional, and local peace, security, and development. Therefore, this study examined the dynamic nature of the ethnic conflict between the Oromo and Somali communities living along the shared border of the Somali and Oromia regional administration, specifically Babile \& Bobas districts respectively, in the context of the federal framework.

\section{Statement of the Problem}

Though the adoption of ethnic federalism as a diagnosis and response to Ethiopia's centurylong divisions between nationalities and history of exploitation has further created challenges at 
various levels in the country, attributed contemporary ethnic conflict solely to ethnic federalism is misjudging and wrong. The new political economy arrangement indeed posed the problem of balancing and reconciling dual identity; challenges related to the question of ethnic groups' relationship and different people and group's relationship within the same nationality, i.e., dualismus vs. and above all led to competition over territory and the border dispute.

The various empirical studies on the sources of ethnic conflict in the area reveal two things; on the one hand, they provide a simplistic explanation by figuring out single factors as the root causes of ethnic conflict. For instance, the competition over resources such as water and pasture land (Shide, 2004; Mesfin, 2006); land ownership and the struggling for exclusive use rights and sole possession (Abdulahi, 2005); lack of good governance (Birru, 2018; Faisal, 2017); unclear boundary demarcation (Kefale, 2013; Hagmann and Mulugeta, 2010; Feyissa, 2014); and ethnic politicization (Asebe, 2012b). On the other hand, they attributed ethnic federalism as the sole factor for Ethiopia's current multi-front crisis and ethnic conflict (Kefale, 2013; Osaghae, 2004; Fessha, 2012; Abebe, 2014; Amnesty International, 2009).

Though all the aforementioned factors have some truths in explaining the ethnic conflict in Ethiopia in general and Oromo-Somali conflict in particular, the author here argues that they are fundamentally weak and flawed in their simplistic explanation of the complex factors behind the conflict which treats ethnic conflict as a direct cause of individual factors and/ or blaming ethnic federalism alone and failed to address the issue within the wider framework of the country's historical, socio-cultural, economic, political arrangements and environmental factors. Consistent with this, the Somali-Oromo conflict is complex and dynamic that cannot be explained by singled out factors. Since 1991 the conflict has changed its shape and nature over time from resources based ethnic conflict to local level territorial conflict and intra-federal boundary dispute along an ethnic line with the involvement of multiple actors and forces and a simple confrontation by using traditional weapons to war-like scenarios with modern and more sophisticated weaponry, the Somali Oromo conflict demands an in-depth analysis of the complex interplay between various national and local factors. Therefore, this particular study investigates and examines the conflict dynamic between the two groups since the adoption of ethnic federalism by using the Oromia and Somali regional states administrative border as a study site; particularly Babile \& Bobas districts as a case study.

The purpose of this study is to analyze ethnic conflict factors and their dynamism along the shared border of Somali and Oromia regional states, i.e., Babile \& Bobas districts respectively, from a comparative perspective. To this end, the study conducted survey questionaries' and attempts were made to examining and organize lessons and experiences of local communities who are directly and indirectly affected by the conflict to generates comprehensive and holistic understanding as well as deep insight into the Somali-Oromo conflict narration which helps government and non-governmental functionalities to design sound conflict resolution mechanism to the end realize sustainable peace and development in the region.

What are the major sources of ethnic conflict in the study area since the adoption of ethnic federalism in the country; 1991? How do you explain those factors? How do you describe the change and continuity of factors (dynamism) of conflict? Who are the actors in the conflict in the study area?

\section{METHODOLOGY}

The study employs a comparative and empirical approach as a research design. This research approach is chosen given its potential to create a situation in which two or more cases are 
empirically contrasted to each other either with a specific phenomenon or along a certain dimension to discover parallels and differences among the cases. Hence, given the overarching goal of this study that is investigating federalism and ethnic conflict dynamics in post-1991 Ethiopia taking the Oromia and Somali regional states as case studies, a comparative approach to politics and society is helpful to analyze the proposed relationships empirically and draw generalizations across time and societal contexts.

\section{Comparative Research Method}

As indicated above, the focal point of this study is investigating federalism and ethnic conflict dynamics in Ethiopia while employing a comparative approach. Though the comparative method is mainly used by pupils of comparative politics interested in developing and testing theories as being applicable beyond the boundaries of a single society (Holt and Turner, 1970), it has also been widely used to analyses diverse political issues within a single country, particularly within federal politics (Bakyis and Chandler, 1987). Therefore, this study examined how the two ethnically defined national regional states (Oromia and Somali regional states), specifically how the Oromo and Somali ethnic groups who live along the shared border of the two different regions, exhibit a considerable degree of comparability in terms of fighting the highland Christian Kingdom, shared linguistic and religious elements, clan-based society, level of socio-economic development, marginality from the center and political volatility, responded to the phenomenon of federal restructuring.

\section{Types and Sources of Data}

To realize the purpose of this study, both qualitative and quantitative types of data are used. Qualitative data was gathered through key informant interviews with the help of interview guide/ open-ended questions and thereby able to capture and describe an individual/group's experience, perceptions, feelings, or emotions regarding factors of ethnic conflict and their dynamism through designing. To generate quantitative data, the study employed survey questionnaires' techniques and was able to administer data from 40 household units, proportionally selected from Oromo and Somali ethnic groups in the two study areas. Primary data sources include local household heads, religious, cultural, and community leaders as well as federal (based on the recommendation of the respective institutional head, House of Federation (HoF) and ministry of Peace (MoP), and local experts (based on the recommendation of the woreda/district administration chief), informants with the necessary knowledge and experience selected and asked about the Oromo-Somali conflict). The researcher traveled from March 19-March 28/2020 to the study site, i.e., Babile and Bobas districts along the East-East shared border of the two regions and from 3 April/2020-17 April/2020 to Addis Ababa thereby collected both types of data quantitative and qualitative from key informants. Secondary data sources include books, reports, legal and policy documents, internet articles, research articles by other researchers (journals), databases, and other sources.

\section{Dependent Variable and Independent Variables}

This study's dependent variable is ethnic conflict within the federal framework. Here, respondents were asked to rate their level of perception/understanding as either very important, important, less important, and not important. Thus, data were coded on a 4-point scale with being "very important" and 4 being "not important".

Various variables that can actually and/or potentially explain ethnic conflict were identified and grouped to suit the respondent's needs. Here again, respondents were given 25 variables and 
asked to rank the sources of ethnic conflict in their locality, and a 4-point scale was developed for the analysis.

\section{Sampling Procedures}

Multi-stage sampling procedures are used to realize research objectives, i.e., subjective/ judgment, simple random, and systematic sampling.

\section{Methods of Data Analysis and Interpretation}

The study employed both qualitative (content, narrative, and qualitative comparative analysis case-oriented understanding) and quantitative (cross-tabulation and the Chi-square test) data analysis and interpretation types to realize its objective.

\section{RESULTS}

\subsection{Federalism and Ethnic Conflict Dynamics in the Ethiopian context}

The result of this study analyzed within the framework of factors of ethnic conflict is dynamics and the sources of ethnic conflict in the two study areas are different. Since 1991 Ethiopia led by EPRDF embarked on a multinational state-building project, unlike its predecessors who engaged in an Ethiopian nation-building project. The institutionalization of a multinational federation in the country not only ended seventeen years of civil war but also paved the way to entertain ethnocultural diversity. Through the federal system, which intends to create a stable political society by recognizing and accommodating the country's lingo-cultural plurality, the country has witnessed more ethnic-based conflict than ever before under these federal arrangements. Many blamed the system for localizing conflict and assert that the introduction of the federal arrangement in Ethiopia since 1991 is responsible for large-scale ethnic conflict and boundary dispute.

Accordingly, conflict analysis in Ethiopia rushes to blame federalism and associated politicization of ethnicity for all of the problems and crises that the country is suffering from. Through the federal arrangement in the country, which created border problems, mobility restrictions, ownership/ entitlement issues, and ethnic dictatorship, are the sources of conflict, it would be wrong and fatal to generalize and claim that federalism in its current shape and arrangement is the sources of all crises in Ethiopia. Similarly, the politicization of ethnicity and elite-based conflict entrepreneurs are not the sole sources of the crisis though they promote victim-based politics and spread false narration and hate between communities, thereby foment ethnic conflict in Ethiopia which is testing the integrity of the state and the basic fabric of the Ethiopian society. Therefore, the sources of ethnic conflict in Ethiopia are complex, dynamic, and multidimensional that cannot be examined in a simplistic term. Broader forces, i.e., historical, institutional/structural/political, economic, socio-cultural, and environmental factors must be taken into account to explain the ethnic conflict in the country. And sources of ethnic conflict in the two study areas are similar.

Table 1, here below, demonstrates the perception of the local population on factors of ethnic conflict where sample respondents were given 25 variables and asked to rank the sources of ethnic conflict in their locality, and a 4-point scale was developed for the analysis. Consequently, factors like fierce competition over pasture land and water resources; absence of clearly defined boundaries; politicization of ethnicity by the political elites, political-economic grievances; proliferation of firearms and small weapons; the introduction of ethnic federalism; ownership rights of custom posts, revenue and market centers; poverty, poor infrastructure and unfair distribution of development activities; environmental degradation, climate variability, drought 
incidence; weak formal and informal (customary) institutional environment; mobility restriction; competition over territory/territorial incursion/land grab; legal and/or illegal settlement and resettlement; lack of good governance; motivation by/pressure from political bodies, armed groups paramilitary forces/others; demographic pressure; deterioration of common values and norms (religious and moral values) in the communities; ancestral land tenure belief /land claim/ reclaim and social/mainstream media pressure/misinformation/fake news are Identified as most important and important drivers of ethnic conflict in the study area while theft of properties/ absence of property rights; sense of ethnic rivals/hostility/hatred; ethnic/identity difference/ ethnocentric view over the other; myth of past atrocities/past harms; heroism and kidnapping and revenge tradition are less important and not important factors of ethnic conflict (See Annex 1).

\section{DISCUSSION}

Table 1 above reveals the distribution of respondent's perceptions regarding major drivers/ factors of ethnic conflict in the study area. Respondents were asked about the importance of the possible sources of recent violent conflicts. The rates were then weighted by the proportion of each possible source and by the total proportion of each rate. Thus, this part is dedicated to analyze and discuss quantitative results which are indeed supported by data obtained through qualitative techniques.

\subsection{Fierce competition over pasture land and water resources}

The vast majority of respondents from both groups (80.0 percent) perceived that fierce competition over pasture land and water resources is the most important factor while others (20.0 percent) responded that it was an important factor and the observed difference between the two groups is not statistically significant with Fisher's Exact Test at 695. Indeed, competition over resources in pastoral and agro-pastoral societies causes conflict given the scarcity of resources and visible demographic pressure. In the pre-1991 system, both Somali and Oromo ethnic groups were administered under the same administration, and access to and utilization of resources is often based on historical claims through kinship and managed in their common institutions. In the post-1991, since ethnicity is the primary principle of administration units, resources access and utilization tide with a given ethnic group in certain boundary demarcation limit access to resources causing discontent motives of conflict on either side. This has created mobility restrictions for a pastoral and agro-pastoral community in the study area and, in effect, ethnic groups in the area involved in competing claims over rangelands and water points. Research participants from the two study areas have demonstrated similar ideas in that fierce competition over pasture, land, and water resources is played and currently playing a major role in instigating ethnic and boundary conflict in the study area.

The information obtained from key informants (expertise from Babile and Bobas districts) reflects that:

...the repeated nature of the conflict in the study area associated with groups desire to expand its territory and grab more land, which is a common response of both the pastoral and agro-pastoral communities to resource scarcity, using violent means to control territorial resources such as grazing and agricultural land and water wells/ponds/ boreholes in violation of customary rules and regulation that enforces fair and equitable resource utilization and management and sanctions those who violets it (Anonymous source 1). 


\title{
4.2 Absence of clearly defined boundaries
}

Almost all respondents from both groups (97.5 percent) responded that the absence of clearly defined boundaries is the most important factor of ethnic conflict while only 2.5 percent perceived it important with Fisher's Exact Test significant level 1.000 indicating the groups studied are more likely the same. The introduction of ethnic federalism in Ethiopia in 1991 created regions along the ethnic line without clear administrative boundaries in different parts of the country. There is an unclear administration boundary along the shared border of the two regions. Despite the various efforts, including the 2004 political referendum, the lack of clear boundaries is the underlying cause of conflict in the study area. Key informant interviews with local experts from the two study areas reveal that the roots of the Oromo-Somali conflict emanate from the absence of a clearly defined administrative border between the two regional administrations. For instance, key informants from Babile and Bobas districts argued that 'neither the 1992 border demarcation nor the 2004/5 political referendum has solved the border issue and the illegal settlement and movement of the communities'; that is why the conflict sustained along the shared border of the two regions. The key informant interview with federal experts reflects that:

\begin{abstract}
It is the lack of clear administrative boundary that fundamentally contributing to the sudden eruption of violent conflict and also to the ongoing ethnic conflict along the shared borders of the two regions. Though we all have delighted when Lema Megersa of Oromia and Abdi Mohammed of Somali met and displayed a historic gesture of unity in 2017 where the two leaders appeared to resolve the issue once and for all while reaching an agreement to complete the border demarcation process pursuant of the 2004/5 referendum. However, the two leaders have failed to respect the terms of the pact. Instead of finding a common solution to their common problem, they have traded blame for the main cause of the recent clashes. Consequently, the two regions immersed into another round of conflict and severe political confrontation unprecedented in contemporary Ethiopian history (Anonymous source 2).
\end{abstract}

\subsection{Theft of properties/ absence of property rights and sense of ethnic rivals/hostility/ hatred}

The result of the survey reveals that theft of properties/ absence of property rights and sense of ethnic rivals/hostility/hatred perceived as less important factors by the majority of the respondents (42.5 percent and 55.0 percent respectively) from both groups while 32.5 percent \& 2.5 percent; 37.5 percent \& 17.5 percent; 7.5 percent \& 5.0 percent responded important, not important and most important factors of ethnic conflict respectively with no statistical difference between the two groups at Pearson Chi-Square .637 and .355 respectively. In low-land areas in Ethiopia, including the Somali and Oromo shared areas, land rights are a loosely defined group of rights that are granted to the clan under the guardianship of clan leaders (Helland, 2006: 6). This kind of arrangement either promotes cooperation or encourages conflict in a given environment though it all depends on different factors. A well-regulated environment with committed customary institutions promotes cooperation, equitable utilization, and management of resources while encouraging conflict if political and cultural recognitions are attached to the clan's ability to control and claim more resource pool. Further, since ethnic groups are the organizing principle of politico-administrative units in the Ethiopian federation, groups are more likely to opt for rival competitions than cooperation over resources.

The key informant interview with local elders from Babile and Bobas districts illustrates that: 
...the civil war in Ethiopia during the military government not only weakened central and regional state institutions but also devastated traditional institutions causing security problems to communal property. The inability of customary institutions, central and local governments to enforce communal property has led to open-access tenure regimes during the transitional period (1991-1992) in low land areas including the border areas of Somali and Oromo. These open-access regimes created a favorable ground for violent confrontations to occur triggered by multiple claims and counterclaims on the same land, pasture, and water points. Thus, this situation had created losers and winners; those groups with better equipment and higher bargaining power have capture strategic resources by force while those who were less organized and weak have lost all the resources to their rival (Anonymous source 3).

In the survey result, the sense of ethnic rivals/hostility/hatred ranked poorly playing less and no important role in instigating conflict in the study area. The same result was discovered in the key informant interview in the sense that it is not hatred/hostilities associated with ethnic/clan identity causing ethnic conflict in the study area rather state/government policy \& associated politicization of ethnicity and community's desire to expand territory.

Key informants from the House of Federation (HoF) and Ministry of Peace have echoed that:

...the conflict is not because Oromo hates Somali and vice versa. Rather, at the core there is first, interest on both parties to expand territory due to the absence of clearly demarcated border; second, internal and external forces spreading mistrusts, hatreds, and ethnic hostilities; third, the politicization of ethnicity as manifested in a power struggle between politicians to control political and economic resources (Anonymous source 2).

Historically, there were no anonymities between the Somali and Oromo communities. They lived together for centuries and in effect, they share many more communalities, like Cushitic-Muslim identity, economic interdependency, marriage, they share common customary institutions to deal with resources utilization, management, and conflict resolution than things that separate them. That is why particularly people in the shared border between the two regions have identified with dual Somali-Oromo identities. However, the new state structure and its associated policy introduced after 1991 established an ethnic border between the two groups by creating a strong association between identity and territory. Then the two groups tend to develop mistrust and a feeling of rivalry/ hostility and begin to quarrel over territory, particularly in those areas previously owned by both communities which are now identified as either the Oromo or Somali territory.

\subsection{Motivation by political bodies / Politicization of ethnicity}

The vast majority of respondents (80.0 percent) rated motivation by political bodies/politicization of ethnicity as the most important factor while only an insignificant portion of the sample population (20.0 percent) perceived important factor as the observed difference between the two groups is not statistically significant at Fisher's Exact Test .235, indicating the groups being studied are most likely similar. Scholars in the area of conflict studies have frequently figured out that political elites and government bodies are responsible for most of the conflict that occurs on the African continent (Segun, 2013). This is true because groups/individuals competition to access and control the state and its political power is the key to wealth (Omoweh and Okanya, 2005). The political-economic environment in Ethiopia is not exceptional and even worse since the state is organized along the ethnic line and the vast majority of political parties in the country are organized based on ethnic identity. The information obtained from the key informant interviewee reveals that the majority of political elites and government bodies in Ethiopia are playing a negative role in triggering and instigating conflict by mobilizing their respective ethnic 
base one against the other by exploiting existing political, economic, socio-cultural, economic, and ethnolinguistic differences just to realize their self-centered interest.

In this regard, key informants from the House of Federation (HoF) and Ministry of Peace (MoP) have put forward that:

The Somali-Oromo communities are a similar community in almost all aspects (sociocultural, economic, political, and environmental settings). The two groups are even living peacefully after the federal rearrangement under the guidance of common traditional institutions. In both communities in general and communities along with the shared border traditional and religious leaders (Oromo's Aba Gadaa and Somali's Ugaz) have more authority and respect than formal authority like local/regional government structures. However, the political economy of the post-1991 has tried and in some way succeeded in politicizing those institutions and their leaders in a way that ruins their reputations and interaction with the local community. In effect, the public began to perceive the existence of two categories of traditional leaders i.e., government appoints who have meaningful support from the government since they just represent government interest and promotes its propaganda and community leader who are loyal to the community and defend their interest but have no support from the government. These political interferences have weakened the integrity and trustworthiness of traditional institutions and their leaders do not play the role that society expects from them. Further, local politicians have intentionally worked to weaken traditional institutions and their leaders with the view to assume real power/authority within the community. Moreover, political elites and government bodies intentionally pursue exclusionist strategies' when it comes to the distribution of socio-economic and political resources to create a mobilization space. Taking the weak and divided customary institutions as an advantage, political elites and government bodies from both groups began to saw the seeds of differences, hatred, and hostilities among and between the communities, citing cultural, historical, and ethnic differences, just for access and control over local and regional power and resources. To this end, they mobilize their respective ethnic base and use violence against the other groups instigating ethnic conflict between communities there (Anonymous source 2).

\subsection{Political-economic grievances}

The majority of respondents (42.5 percent) ranked political-economic grievances as important factors while others 20.0 percent, 20.0 percent, and 17.5 percent responded most important, less important, and not important factors of ethnic conflict respectively. The Pearson Chi-Square test at .421 confirmed that the groups being studied are similar where the observed difference between the two groups is not statistically significant. In Africa, ethnopolitical conflicts are associated with marginalization where state policy lacks inclusiveness and doesn't reflect the ethnolinguistic diversity of the state on the ground. That is why Jinadu (2007) treated the ethnopolitical crisis in the continent as both an outcome and an indirect cause of the political-economic crisis of African states. The Ethiopian experience is not exceptional where successive governments had inflicted injustice on the majority of the population while benefiting the few in the distribution of resources, including political power.

Key informant interviews with local and federal experts have demonstrated that:

...in the EPRDF system political parties governing peripheral regions like the Somali, Afar, Gambella... are not part of the central government's executive branch and in effect, have no role in the top-down policy and decision-making process. This not only violates constitutional provisions, which grants regions self-autonomy in policy-making as per to local 
demands but also policies made at the center often overlook the needs and interest of pastoral and agro-pastoral communities like those who live along the shared border of the Somali and Oromia regional administration which often results in political and economic grievances at the local level. Political and economic grievances from lack of employment opportunities, absence of political participation and inclusiveness, lack of access to market, and poor infrastructural development have ignited conflict in the study area. This can be witnessed from the 2015-2017/18 Oromo movements (Qerro/Youth movement) across the Oromia region generating violent conflict not only with the central government but also with their neighbor Somali communities (Anonymous source 1 and Anonymous source 2).

From this one can infer that both communities were oppressed and marginalized, and in effect, there are widespread political-economic grievances causing political instability and conflict in the two regions. When people have no appropriate channel to express their concerns and politicaleconomic grievances, then they would pursue a violent way to pressure the government and make their voice heard. The nationwide violent protest that erupted since 2015-2018 was largely due to political and economic marginalization. The protest gradually took an ethnic line, and the youth began to attack ethnic others in their respective regions; the Somali turned against the Oromo and vice versa.

\subsection{Ethnic/identity difference/ ethnocentric and Myth of past atrocities/ revenge of past harms}

The majority of respondents (57.5 percent \& 52.5 percent) ranked ethnic/identity difference/ ethnocentric view over the other and myth of past atrocities/ revenge of past harms as less important and not important sources of conflict respectively while 25.0 percent \& 15.0 percent as important factors and 17.5 percent \& 32.5 percent of the sample population rated as not important and less important factors in the same order with no observed statistical difference between the two groups at Pearson Chi-Square .344 and .673 respectively. As indicated in the survey finding, ethnic identity difference and superiority feeling between groups ranked less and not important factors in instigating conflict in the study area. The Oromo and Somali communities who live along the shared border defined themselves as having a dual identity (Somali-Oromo identity). Ethnic differences and associated attributes have no role in determining their interaction. Key informants from woreda/district administrations have also downplayed the role of ethnic difference and ethnocentric view one against the other as playing an important role in igniting ethnic conflict in the study area. The researcher has also observed that the Somali and Oromo communities are similar in every aspect like dressing patterns, they speak each other's language, trade each other using either language, integrate with marriage, worship in the same mosque.

As indicated in the survey result, the myth of past harms and atrocities ranked important, less important, and not important factors of ethnic conflict in the study area. The information obtained from the key informants has reflected that myth of past harms and atrocities has no role in the Somali-Oromo conflict.

Key informant interview with local elders and expertise from both study areas illustrates that:

...deadly conflict and associated atrocities had never occurred between the two communities in the past. In the past conflicts were seasonal and there were no recorded atrocities like a gross violation of human rights, mass killings, and mass sexual assaults although the 2017/18 Oromo-Somali conflict was violent and destructive. Further, resource allocation mechanisms are managed under common institutions where ethnic \& religious criteria had no role since such criteria are incompatible with the very purpose of customary institutions (Anonymous source 3 and Anonymous source 1). 
4.7 The proliferation of firearms and small weapons; the introduction of ethnic-based boundaries, and ownership rights of custom posts and market centers

The great majority of respondents (70.0 percent, 82.5 percent \& 95.0 percent) ranked proliferation of firearms and small weapons; introduction of ethnic-based boundaries, and ownership rights of custom posts and market centers as the most important factors respectively while others 30.0 percent, 17.5 percent and 5.0 percent rated as important factors of ethnic conflict in the same order with the observed difference between groups is not statistically significant at Pearson Chi-Square .490 and Fisher's Exact Test of 1.000 and 1.000 respectively. In the group discussion, the author has captured the major movements of arms in the study area. The Somali accuses the Oromo of their link with OLF and access to firearms and small weapons and similarly the Oromo accuses the Somali not only for their link and access to the weapon through ONLF but also for their free access to weapons given their location to Djibouti, Somali land, and Somalia as well as the military and moral support that they obtained from the state of Somalia. Though the introduction of federalism paved the way for lingo-cultural celebration across the country, ethnicbased administration has brought serious tensions and conflicts between communities within the same regions and between regions at least in three forms, i.e., the border problem; the issue of ownership/entitlement (them vs. us dichotomy) and ethnic dictatorship. The Oromo and Somali communities share more commonality than what separates them, but the ethnic administration installed rigid boundaries between them restricting the free movements of pastoral and agropastoral communities who reside along the shared border of the two regions.

\subsection{Poverty/ inequality/unfair distribution of development activities/; Environmental de- gradation /climate variability/drought incidence and Weak formal and informal (custo- mary) institutional environment}

From the sample population 60.0 percent, 80.0 percent, and 42.5 percent ranked poverty/ Inequality/unfair distribution of development activities/; environmental degradation /climate variability/drought incidence and weak formal and informal (customary) institutional environment as most important factors of ethnic conflict respectively while 40.0 percent, 20.0 percent, and 57.5 percent rated as important factors in the same order with no statistically significant difference between the two groups at Pearson Chi-Square .519, Fisher's Exact Test .695 and Pearson ChiSquare significant level at .749 in that order. The information gathered from key informants from the HoF and MoP demonstrates that 'the central government for years neglected their area considering it as a periphery, and in effect, they suffered a lot from the absence of infrastructural development and prevalence of poverty which can be a source of instigating conflict' (Anonymous source 2). Further, environmental degradation and climate variability and associated impacts like droughts, flooding, and desert locust swarm contributed to the occurrence of violent conflict in the study area, as revealed in the interview. Moreover, key informants have underlined that formal institutions like stating institutions and party structure and informal institutions like religious/ cultural and customary institutions are very weak to enforce rule of law, property rights and limit groups/individuals of opportunistic behaviors. The problem is acute when there is nationwide political instability, for instance, when Abiy Ahmed Ali ascends to power in 2018, soon violent conflict erupted not only between the Somali and Oromo communities but also across the country. 
4.9 Competition over territory/territorial incursion/land grab, Mobility restriction and Motivation by/pressure from armed groups paramilitary forces/other

The vast majority of respondents (87.5 percent) perceived competition over territory/territorial incursion/land grab as the most important factor and only 12.5 percent ranked it important while 42.0 percent, 25.0 percent, and 22.5 percent of the sample population rated mobility of restriction as important, most important and less important factors of ethnic conflict respectively and the observed difference between the two groups is not statistically significant at Fisher's Exact Test 1.000 and Pearson Chi-Square of .666 in that order. 55.0 percent \& 60.0 percent and 45.0 percent \& 40.0 percent respondents from the sample population ranked motivation by/pressure from armed groups, paramilitary forces/other and deterioration of religious and moral values in the communities as the most important and important factors of ethnic conflict respectively with statistical significance at Pearson Chi-Square .525 and .519 in that order confirming that the groups being studies are the same. As confirmed in the key informant interview, competition over territory is the major factor of conflict in the study area since revenue from land and resources provides the means to sustain the conflict. There are overlapping rights and claims to land and resources, and in effect, each group engaged in territorial incursion/land grab in their way. Rigid administrative boundaries put mobility restrictions in search of pasture land and water points, instigating conflict between the two communities. Further, the conflict in the area is fueled by inflammatory forces like paramilitary forces, rebel groups like OLF and ONLF as well as federal civil and military personnel who have vested interest in the Somali region provide implicit and explicit supports when groups enter into open violent conflicts (see Table 1). Moreover, religious and cultural institutions were hijacked by the ruling EPRDF forces and failed to execute their Godgiven duties and society's expectation, and, in effect, widespread moral anarchism and value crisis became the governing principles across society, as revealed in the key informant interview.

\subsection{Legal and/or illegal settlement \& resettlement, Lack of good governance, and Demo- graphic pressure}

From the sample population, a great majority of respondents 70.0 percent, 80.0 percent, and 75.0 percent ranked factors like legal and/or illegal settlement \& resettlement, lack of good governance, and demographic pressure as the most important factors while 30.0 percent, 20.0 percent, and 25.0 percent of the sample population perceived them as important factors of ethnic conflict respectively and the observed difference between groups is not statistically significant at Pearson Chi-Square .490, Fisher's Exact Test .695 and Pearson Chi-Square .465 in that order. Since there are overlapping rights and claims to land and resources, groups are often in a state of competition to control certain territory, which is usually done by resettling their population on disputed land, instigating conflict between the two groups as revealed in the key informant interview. In Ethiopia, the lack of democratic culture, the erosion of the rule of law, party monopolization of the economy, as well as the politicization of the civil service, the incidence of grand and petty corruption continued to be major sources of bad governance and constitute a major explanation of ethnic conflict in the country. Communities are aware of the impact of population pressure (both livestock and human) on available resources and how it creates a breeding ground for conflicts.

\subsection{Kidnapping, revenge tradition and Heroism}

The majority of respondents (60.0 percent \& 75.0 percent) ranked kidnapping \& revenge tradition and heroism as not important factors while 40.0 percent and 25.0 percent treated them as less important factors of ethnic conflict respectively with no statistical difference between the two groups; Pearson Chi-Square .519 and .465 in that order. 
Customs of kidnapping, revenge, and heroism has no place in the eastern society, including the Oromo and Somali culture, though it is practiced dominantly in the northern society and some other parts of Ethiopia. The interview results also confirm that belief system like the practice of heroism and revenge is not the primary sources of conflicts in the study area, though both communities do have cultural beliefs and attachment to claim and counterclaim ancestral lands, which constitutes major sources of conflict between the two communities. The key informant interview with local elders revealed that there are cattle raiding and counter raiding between the two groups although the violence is not related to heroism, revenge, and some other cultural beliefs rather it is conducted just for an economic reason'.

The vast majority of respondents ( 82.5 percent \& 75.0 percent) rated ancestral tenure/land claim/reclaim and social/mainstream media pressure as most important while 17.5 percent \& 25.0 percent ranked as important factors respectively with statistical significance Fisher's Exact Test 1.000 and Pearson Chi-Square .144, suggesting it is more likely that the group being studied are the same. Both groups in the discussion have admitted that there are historical and ancestral claims and counterclaims not only over disputed areas along the shared border of the two regions but also territories far from their current administration boundary which often leads the two communities in a vicious circle of conflict. The problem is further complicated by the absence of a clear modern administrative boundary along the shared border of the two regions. Both groups in the discussion have complained about the negative role of regional, national and international media as well as social media feeding people fear, hatred, and calling for genocides and attacks against specific religious and ethnic groups. Though social media such as Facebook played a vital role in the collapse of the EPRDF authoritarian government, its inaction helped propagate hate and polarization in the country and has a devastating impact on the narrative and extent of violence in the country. Mainstream national/regional as well as private Media like Ethiopian News Network (ENN), Oromo Media Network (OMN), Dimtsi Weyane (DW), Tigray Television are actively engaged in spreading false and manipulative narratives with a phenomenal case. Furthermore, during the 2017 and 2018 crisis regional government and party leaders in both regions (Somali and Oromia regional states) were weaponizing regional TV channels and being used as tools to incite violence and foment ethnic conflict.

\section{CONCLUSION}

Since 1991 Ethiopia has adopted federalism in response to its century-long contradiction related to ethnocultural diversity. The federal arrangement paved the way for lingo-cultural celebration and the creation of self-rule administration in various parts of the country. Accordingly, the 1994/5 constitutions established nine self-administrative regions and the Somali and Oromia regions are the two largest regions in the federation that share a border of more than $1000 \mathrm{~km}$. Communities in the two regions in general and along the shared border in particular share more things in common than issues that separate them due to their century of interactions. Similarly, the two ethnic groups have experienced antagonistic relationships and intermittent conflicts throughout their history of existence through the nature, behaviors, and trends of conflict varied from time to time. However, studies on conflict analysis in the regions were rushes to blame federalism and associated politicization of ethnicity as well as traditional sources like competition over scarce resources for all of the problems and crises related to ethnic conflict along the shared border of the two regions. Though the aforementioned factors play a significant role in instigating ethnic conflict in the study area, limited conflict analysis in the study area to those factors is shallow and fundamentally flawed. Therefore, forces that drive communities along the shared border of the two regions into ethnic conflict are complex, dynamic, and multidimensional that cannot be examined in a simplistic term. Broader forces, i.e., historical, institutional/structural/political, 
economic, socio-cultural, and environmental factors must be taken into account in explaining the ethnic conflict in the study area. Therefore, the recurrent nature of Somali-Oromo conflict must be seen as a nexus between ethnic federalism and other factors including changing political and administrative dynamics at macro and micro level, emerging identity construction and or reconstruction, the collapse of social norms, and prevalence of moral anarchism, socio-economic dynamics, competing interest among public and military officials, leadership and governance system, internal and external forces, competing interest over resources, aspects of local cultural institutions in regulating inter-ethnic relationship in fueling the conflict. The research is limited both by the geographical setting and time. It is conducted on the east-east border sharing of the two regions, taking only two districts as the study site, and the paper also covers factors of ethnic conflict in post-1991 Ethiopia, after the adoption of ethnic federalism. The researcher recommends that future research in the study area should focus on the east-west and southern shared borders of the two regions so as to generate comprehensive results regarding factors of ethnic conflict. Furthermore, a future investigation should also look into pre-1991 factors of ethnic conflict in the study area and compare and contrast it with the post-1991 research results on factors of ethnic conflict.

\section{REFERENCES}

Abbink, J. (2006). Ethnicity and Conflict Generation in Ethiopia: Some Problems and Prospects of Ethno-Regional Federalism. Journal of Contemporary African Studies, 24(3), 389-413. https://doi. org/10.1080/02589000600976729

Abdulahi, M. (2005). The changing nature of pastoral conflicts in south-eastern Ethiopia: The case of the Boran and Digodi pastoralists. Interafrica Group, Saferworld.

Abebe, S. G. (2014). The Last Post-Cold War Socialist Federation (1 st Edition). Routledge

Ali, K. (2005). Conflict and conflict resolution in Somali regional state. Final consultancy report for GTZ, Capacity Building in Governance Conflict Prevention 1 Transformation CPT. Ministry of Federal Affairs (MFA).

Birru, T. J. (2018). Federalism and Inter-Clan Relations along the Regional Borders of Oromia and Somali: A Case Study of Liban and Filtu Woredas [Doctoral Dissertation, Addis Ababa University] http://localhost/ xmlui/handle/123456789/12633

Clapham, C. (2009). Post-war Ethiopia: The Trajectories of Crisis. Review of African Political Economy, 36(120), 181-192. https://doi.org/10.1080/03056240903064953

Debelo, A. R. (2012). Emerging Ethnic Identities and Inter-Ethnic Conflict: The Guji-Burji Conflict in South Ethiopia, 517-533. Studies in Ethnicity and Nationalism, 12(3), 2012 https://doi.org/10.1111/sena.12007

Donham, D. L., and James, W. (2002). Southern Marches of Imperial Ethiopia: Essays in History and Social Anthropology (Eastern African Studies). Oxford.

Eshete, A. (2003, May 5th-7th ). Ethnic Federalism: New Frontiers in Ethiopian Politics. [Conference] 1st National Conference on Federalism, Ministry of Federal Affairs and GTZ, Addis Ababa, Ethiopia.

Fessha, Y. (2012). Federalism, Territorial Autonomy and the Management of Ethnic Diversity in Africa: Reading the Balance Sheet. L'Europe en Formation, 363, 265-285. https://doi.org/10.3917/eufor.363.0265

Feyissa, T. K. (2014). Conflicts among Pastoralists in the Borana Area of Southern Ethiopia: The case of Borana and Garri. [Master's Thesis, University of Troms $\varnothing$ ] https://hdl.handle.net/10037/7158

Getachew, K. (2002). An overview of root causes of problems that currently affect Borana pastoralists of southern Ethiopia. In Babiker, Mustafa (ed) Resource Alienation, Militarization and Development: Case studies from East Africa Dry lands. Proceedings of the Regional Workshops on East African Dry lands (pp. 67-76) Khartoum and Addis Ababa.

Getachew, M. (2006). Ethnicity and Ethnic-Conflict in Post-Federal Ethiopia: A case of Maiso District Conflict between Oromos and Somalis. EPU 
Hagmann, T., \& Abbink, J. (2011). Twenty years of revolutionary democratic Ethiopia, 1991 to 2011. Journal of Eastern African Studies, 5(4), 579-595. https://doi.org/10.1080/17531055.2011.642515

Hagmann, T., \& Mulugeta, A. (2008). Pastoral Conflicts and State-Building in the Ethiopian Lowlands. Africa Spectrum, 43(1), 19-37. http://www.jstor.org/stable/40175220

Hashim, T. (2010). Transition to Federalism: The Ethiopian Experience. Forum of Federations.

Helland, J. (2006, October 30-31). Land Tenure in the Pastoral Areas of Ethiopia. [Conference] International Research Workshop on Property Rights, Collective Action and Poverty Reduction, Ethiopia, October 30-31

International Crisis Group (4 September 2009). Ethiopia: ethnic federalism and its discontents. Africa Report, 153 https://cutt.ly/iQfoZIA

Joshua, S. (2013). Politics and Conflicts: a study of Ebiraland, Nigeria (1977-2007). (Doctoral Thesis, Covenant University) http://eprints.covenantuniversity.edu.ng/id/eprint/1458

Kefale, A. (2013). Federalism and Ethnic Conflict in Ethiopia. A Comparative Regional Study (1 st edition), Routledge https://doi.org/10.4324/9780203759530

Keller, E. J. (1988). Revolutionary Ethiopia: From Empire to Peoples' Republic. Indiana University Press.

Liban, M. O. (2006, December). Local conflicts between Somali and Oromo people in the context of political decentralization in Ethiopia: Comparative case study on Ma'eso and Babile Districts. (Master thesis, Institute of Social Studies). http://www.secheresse.info/spip.php?article56490

Markakis, John (1987). National and Class Conflict in the Horn of Africa. Cambridge University Press.

OCHA and the National Disaster Risk Management Commission (NDRMC) (2018, 23). January. Ethiopia: Conflict Displacement Situation Report. https://cutt.ly/RQfpf55

Roble, F. (2017, September 27). Roots to the Somali Massacre: Challenging False Narrative. Wardheer News. https://cutt.ly/gQfpgve

Shide, A. (2004). Conflicts along Oromia-Somali States Boundaries: the case study of Babile districts. [Conference] First national conference on federalism, conflict, and peace building, organized by the Ethio-German co-operation (GTZ) of The Federal Governance Development Project in collaboration with the Ministry of Federal Affairs. Addis- Ababa, Ethiopia.

The Proclamation of FDRE Constitution (1995). Addis Ababa: Berhanina Selam Printing Press. https://www. wipo.int/edocs/lexdocs/laws/en/et/etoo7en.pdf

\section{AUTHOR}

Takele Bekele Bayu. Ph.D. Candidate, the Doctoral School of Public Administration Science, National University of Public Service, Budapest-Hungary. Dean, College of Social Science and Humanities, Dire Dawa University, Dire

Dawa, Ethiopia Lecturer, Department of Pedagogy and Morality, Dire Dawa University, Dire Dawa, Ethiopia Conflicting Interest

The author declares that there is no conflict of interest.

$$
\text { Funding }
$$

The author received no financial support for the research, authorship, and /or publication of this article.

$$
\text { Acknowledgments }
$$

First of all, I am thankful to the Almighty God. This work is the result of the free participation and expert contribution of some of the people whom I know during my Ph.D. career. I must recognize and acknowledge the local administration in Oromia and Somali regional states for their full cooperation and support during my data collection period. I am thankful to the local sample respondents for their commitment to filling the survey questionaries' and sharing their experiences and thought in the focus group discussion.

My profound thanks also go to Professor Marsai Viktor for his all-rounded support and supervision of my ongoing Ph.D. dissertation and the accomplishment of this particular article. 
Annex 1.

Local perception on factors of ethnic conflict

\begin{tabular}{|c|c|c|c|c|c|}
\hline \multirow[t]{2}{*}{ Factors of Ethnic conflict } & \multirow[t]{2}{*}{ Ranking } & \multicolumn{3}{|c|}{ Respondent districts } & \multirow[t]{2}{*}{ Chi-Square Test } \\
\hline & & Babile-Oromia & Bobas-Somali & Both & \\
\hline \multirow{2}{*}{$\begin{array}{l}\text { Fierce competition over pasture land } \\
\text { and water resources }\end{array}$} & most important count & $15(75.0)$ & $17(85.0)$ & $32(80.0)$ & \multirow[t]{2}{*}{$.695^{* *}$} \\
\hline & important count & $5(25.0)$ & $3(15.0)$ & $8(20.0)$ & \\
\hline \multirow{2}{*}{$\begin{array}{l}\text { Absence of clearly defined bound- } \\
\text { aries }\end{array}$} & most important count & $19(95.0)$ & $20(100.0)$ & $39(97.5)$ & \multirow[t]{2}{*}{$1.000^{* *}$} \\
\hline & important count & $1(5.0)$ & $\mathrm{o}(0.0)$ & $1(2.5)$ & \\
\hline \multirow{4}{*}{$\begin{array}{c}\text { Theft of properties/ Absence of } \\
\text { property rights }\end{array}$} & most important count & $1(10.0)$ & $2(25.0)$ & $3(7.5)$ & \multirow[t]{4}{*}{$.637^{*}$} \\
\hline & important count & $5(25.0)$ & $8(40.0)$ & $13(32.5)$ & \\
\hline & less important count & $10(50.0)$ & $7(35.0)$ & $17(42.5)$ & \\
\hline & not important count & $4(20.0)$ & $3(15.0)$ & $7(17.5)$ & \\
\hline \multirow[t]{4}{*}{ Sense of ethnic rivals/hostility/hatred } & most important count & $2(10.0)$ & $\mathrm{o}(0.0)$ & $2(5.0)$ & \multirow[t]{4}{*}{$.355^{*}$} \\
\hline & important count & $\mathrm{o}(0.0)$ & $1(5.0)$ & 1(2.5) & \\
\hline & less count important & $10(50.0)$ & $12(60.0)$ & $22(55.0)$ & \\
\hline & not important count & $8(40.0)$ & $7(35.0)$ & $15(37.5)$ & \\
\hline \multirow{2}{*}{$\begin{array}{l}\text { Motivation by political bodies / Politi- } \\
\text { cization of ethnicity }\end{array}$} & most important count & $14(70.0)$ & 18(90.0) & $32(80.0)$ & \multirow[t]{2}{*}{$.235^{* *}$} \\
\hline & important count & $6(30.0)$ & $2(10.0)$ & $8(20.0)$ & \\
\hline \multirow[t]{4}{*}{ political-economic grievances } & most important count & $5(25.0)$ & $3(15.0)$ & $8(20.0)$ & \multirow[t]{4}{*}{$.421^{*}$} \\
\hline & important count & $10(50.0)$ & $7(35.0)$ & $17(42.5)$ & \\
\hline & less important count & $3(15.0)$ & $5(25.0)$ & $8(20.0)$ & \\
\hline & not important & $2(10.0)$ & $5(25.0)$ & $7(17.5)$ & \\
\hline \multirow{3}{*}{$\begin{array}{l}\text { Ethnic/identity difference/ ethnocen- } \\
\text { tric view over the other }\end{array}$} & important count & $7(35.0)$ & $3(15.0)$ & $10(25.0)$ & \multirow[t]{3}{*}{$344^{*}$} \\
\hline & less important count & $10(50.0)$ & $13(65.0)$ & $23(57.5)$ & \\
\hline & not important count & $3(25.0)$ & $4(20.0)$ & $7(17.5)$ & \\
\hline \multirow{3}{*}{$\begin{array}{c}\text { myth of past atrocities/ Revenge of } \\
\text { past harms }\end{array}$} & important count & $2(10.0)$ & $4(20.0)$ & $6(15.0)$ & \multirow[t]{3}{*}{$.673^{*}$} \\
\hline & less important count & $7(35.0)$ & $6(30.0)$ & $13(32.5)$ & \\
\hline & no important count & $11(55.0)$ & $10(50.0)$ & $21(52.5)$ & \\
\hline \multirow{2}{*}{$\begin{array}{l}\text { Proliferation of firearms and small } \\
\text { weapons }\end{array}$} & most important count & $15(75.0)$ & $13(65.0)$ & $28(70.0)$ & \multirow[t]{2}{*}{$.490^{*}$} \\
\hline & important count & $5(25.0)$ & $7(35.0)$ & $12(30.0)$ & \\
\hline \multirow{2}{*}{$\begin{array}{c}\text { Introduction of ethnic based bound- } \\
\text { aries }\end{array}$} & most important count & $17(85.0)$ & $16(80.0)$ & $33(82.5)$ & $1.000^{* *}$ \\
\hline & important count & $3(15.0)$ & $4(20.0)$ & $7(17.5)$ & \\
\hline Ownership rights of custom posts & most important count & 19(95.0) & 19(95.0) & $38(95.0)$ & $1.000^{* *}$ \\
\hline and market centers & important count & $1(5.0)$ & $1(5.0)$ & $2(5.0)$ & \\
\hline Poverty/ Inequality/unfair distribution & most important count & $13(65.0)$ & $11(55.0)$ & $24(60.0)$ & $.519^{*}$ \\
\hline of development activities/ & important count & $7(35.0)$ & $9(45.0)$ & $16(40.0)$ & \\
\hline Environmental degradation /climate & most important count & $15(75.0)$ & $17(85.0)$ & $32(80.0)$ & $.695^{* *}$ \\
\hline varladima/Drougnt inciaence & important count & $5(25.0)$ & $3(15.0)$ & $8(20.0)$ & \\
\hline Weak formal and informal (custom- & most important count & $8(40.0)$ & $9(45.0)$ & $17(42.5)$ & $.749^{*}$ \\
\hline & important count & $12(60.0)$ & $11(55)$ & $23(57.5)$ & \\
\hline Mobility restriction & most important count & $6(30.0)$ & $4(20.0)$ & $10(25.0)$ & $.666^{*}$ \\
\hline & important count & $8(40.0)$ & $9(45.0)$ & $17(42.5)$ & \\
\hline & less important count & $5(25.0)$ & $4(20.0)$ & $9(22.5)$ & \\
\hline & no important count & $1(5.0)$ & $3(15.0)$ & $4(10.0)$ & \\
\hline Competition over territory/Territorial & most important count & 18(90.0) & $17(85.0)$ & $35(87.5)$ & $1.000^{* * *}$ \\
\hline Incursion/Land grab & important count & $2(10.0)$ & $3(15.0)$ & $5(12.5)$ & \\
\hline Heroism & less important count & $4(20.0)$ & $6(30.0)$ & $10(25.0)$ & $.465^{*}$ \\
\hline & no important count & $16(80.0)$ & $14(70.0)$ & $30(75.0)$ & \\
\hline
\end{tabular}




\begin{tabular}{|c|c|c|c|c|c|}
\hline \multirow{2}{*}{$\begin{array}{l}\text { Legal and/or illegal settlement and } \\
\text { resettlement }\end{array}$} & most important count & $15(75.0)$ & $13(65.0)$ & $28(70.0)$ & \multirow[t]{2}{*}{$.490^{*}$} \\
\hline & important count & $5(25.0)$ & $7(35.0)$ & $12(30.0)$ & \\
\hline \multirow[t]{2}{*}{ Lack of good governance } & most important count & $15(75.0)$ & $17(85.0)$ & $32(80.0)$ & \multirow[t]{2}{*}{$.695^{* *}$} \\
\hline & important count & $5(25.0)$ & $3(15.0)$ & $8(20.0)$ & \\
\hline \multirow{2}{*}{$\begin{array}{l}\text { Motivation by/pressure from armed } \\
\text { groups paramilitary forces/other }\end{array}$} & most important count & $12(60.0)$ & $10(50.0)$ & $22(55.0)$ & \multirow[t]{2}{*}{$.525^{*}$} \\
\hline & important count & $8(40.0)$ & $10(50.0)$ & $18(45.0)$ & \\
\hline \multirow[t]{2}{*}{ Demographic pressure } & most important count & $16(80.0)$ & $14(70.0)$ & $30(75.0)$ & \multirow[t]{2}{*}{$.465^{*}$} \\
\hline & important count & $4(20.0)$ & $6(30.0)$ & $10(25.0)$ & \\
\hline \multirow{2}{*}{$\begin{array}{l}\text { Deterioration of religious and moral } \\
\text { values in the communities }\end{array}$} & most important count & $11(55.0)$ & $13(65.0)$ & $24(60.0)$ & \multirow[t]{2}{*}{$.519^{*}$} \\
\hline & important count & $9(45.0)$ & $7(35.0)$ & $16(40.0)$ & \\
\hline \multirow[t]{2}{*}{ Ancestral Tenure /land claim/reclaim } & most important count & 16(80.0) & $17(85.0)$ & $33(82.5)$ & \multirow[t]{2}{*}{$1.000^{* *}$} \\
\hline & important count & $4(20.0)$ & $3(15.0)$ & $7(17.5)$ & \\
\hline \multirow[t]{2}{*}{ Kidnapping and revenge tradition } & less important count & $7(35.0)$ & $9(45.0)$ & $16(40.0)$ & \multirow[t]{2}{*}{$.519^{*}$} \\
\hline & no important count & $13(65.0)$ & $11(55.0)$ & $24(60.0)$ & \\
\hline \multirow[t]{2}{*}{ Social/mainstream media pressure } & most important count & $13(65.0)$ & $17(85.0)$ & $30(75.0)$ & \multirow[t]{2}{*}{$.144^{*}$} \\
\hline & important count & $7(35.0)$ & $3(15.0)$ & $10(25.0)$ & \\
\hline
\end{tabular}

Note: Significance level 0.5\% *Pearson Chi-Square; **Fisher's Exact Test; Figures in Parenthesis are percentile (\%);

Source: Field Survey (2020) 